\title{
Repeated DNA and heterochromatin structure in Rumex acetosa
}

\author{
MELODY S. CLARK*, JOHN S. PARKER* $\ddagger \&$ CHARLES C. AINSWORTH $\dagger$ \\ *School of Biological Sciences, Queen Mary and Westfield College (University of London), Mile End Road, London, and \\ tDepartment of Biochemistry and Biological Sciences, Wye College (University of London), Wye, Kent, U.K.
}

\begin{abstract}
Seven clones, six of which represent moderate to highly repeated sequences, were isolated from a plasmid clone bank of EcoRI-digested Rumex acetosa DNA. All sequences revealed a dispersed nature when chromosomes were probed by in situ hybridization. Studies of RNA transcription by these sequences indicate that one, pRa141, may be actively transcribed. The implications of these results on the current understanding of the nature of the chromatin in the $R$. acetosa Y chromosome are discussed. Preliminary evidence is produced for a facultative heterochromatic sex system in plants.
\end{abstract}

Keywords: banding, DNase I sensitivity, heterochromatin, in situ hybridization, repetitious DNA, transcription.

\section{Introduction}

Repeated DNA sequences are ubiquitous in higher eukaryote genomes and may constitute the major proportion of the total genomic DNA. In higher plants with large genome sizes, in particular the cereals, repeated DNA sequences can be responsible for 60-80 per cent of the genome (Flavell et al., 1974; Rimpau et al., 1978; Leutwiler et al., 1984).

Repeated DNA sequences have been isolated and characterized from a number of plants, the most intensively studied being the crop species such as wheat (Dennis et al., 1980), rye (Bedbrook et al., 1980) and tomato (Ganal et al., 1988). Although some of these sequences have been identified as coding for ribosomal DNA (Dennis et al., 1980; Ganal et al., 1988) or have homology and retrotransposons (Grandbastien et al., 1989), the function of the majority remains unknown.

Physical mapping of plant repeated sequences onto chromosomes by in situ hybridization has correlated their presence with heterochromatic blocks (Appels et al., 1981; Hutchinson \& Lonsdale, 1982; Jones \& Flavell, 1982a; Viotti et al., 1985). Traditionally, heterochromatin in plants has been assumed to be of a constitutive nature with no known transcriptional activity. The function and significance of repeated DNA sequences remains an enigma: they are invariably

Correspondence: Dr Melody Clark, School of Biological Sciences, Queen Mary and Westfield College (University of London), Mile End Road, London E1 4NS, U.K.

$\ddagger$ Present address: Dept. of Botany, University of Reading, Whiteknights, Reading, Berks, U.K. non-coding (Grellet et al., 1986; Sakowicz et al., 1986; Reddy et al., 1989), are associated with 'inert' DNA structures, yet can be present in massive quantities. These sequences are held to be one of the main reasons for the massive variation in genome size found in the plant kingdom (Bennett et al., 1982). This study was conducted to further elucidate the relationship between repeated DNA and heterochromatin in a plant with a novel heterochromatin distribution.

Rumex acetosa is a dioecious flowering plant with a highly developed sex chromosome system: $2 n=2 x=14(X X)$ in the female and $2 n=2 x=15$ $\left(X Y_{1} Y_{2}\right)$ in the male (Parker \& Clark, 1991). The only heterochromatin in the complement is located within the sex chromosome system. By conventional staining the Xs are euchromatic, whilst the Ys are almost entirely heterochromatic (Wilby \& Parker, 1986). During cell division, the Ys are late-replicating and appear heterochromatic with chromocentres in the interphase nuclei (Zuk, 1969). Only a tiny portion adjacent to one telomere on each $Y$ appears to be euchromatic. The standard autosomes contain no discernible heterochromatin (as visualized in interphase nuclei as chromocentres) although the species is polymorphic for heterochromatic supernumerary segments on chromosomes 1 and 6.

In this paper we report the isolation and characterization of highly repeated sequences from the $R$. acetosa genome. Seven non-homologous classes of clones were isolated, their copy number and organization are reported, together with further cytological characterization of the sex chromosome system. 


\section{Materials and methods}

\section{DNA extraction}

Leaves were frozen in liquid nitrogen and rapidly ground to a fine powder with a mortar and pestle. The powder was re-suspended in 2 volumes of $100 \mathrm{mM}$ Tris pH $8 / 100 \mathrm{mM} \mathrm{NaCl} / 50 \mathrm{mM}$ EDTA $\mathrm{pH} 8 / 2$ per cent SDS $/ 2$ per cent $\mathrm{PVP} / 1.5 \mathrm{mg}$ proteinase $\mathrm{K}$ and incubated at $55^{\circ} \mathrm{C}$ for $3 \mathrm{~h}$. The solution was phenol/ chloroform extracted three times and nucleic acids precipitated with 0.6 volumes of isopropanol. The DNA was dissolved in $5 \mathrm{ml} \mathrm{TE}$ (Tris/EDTA) buffer and purified by caesium chloride density gradient centrifugation.

\section{Clone bank construction}

Total Rumex DNA was digested with EcoRI and cloned using $\mathrm{T}_{4}$ DNA ligase into the EcoRI site of pUC18. After transformation into the E. coli strain JM109, recombinant clones were selected on X-gal/ IPTG plates with $60 \mu \mathrm{g} \mathrm{ml}^{-1}$ ampicillin.

\section{Clone selection}

Recombinant clones were colony blotted onto Hybond $\mathrm{N}$ nylon membranes (Amersham) according to Sambrook et al. (1989). Colony lifts were pre-hybridized in $3 \times \mathrm{SSC} / 0.02$ per cent ficoll $/ 0.02$ per cent $\mathrm{PVP} / 1$ per cent SDS $/ 50 \mu \mathrm{g} \mathrm{ml}^{-1}$ sheared, denatured salmon sperm DNA for $1 \mathrm{~h}$ at $65^{\circ} \mathrm{C}$. Pre-hybridized blots were hybridized with $500 \mathrm{ng}$ of ${ }^{32} \mathrm{P}$ nick-translated total Rumex acetosa male genomic DNA in the buffer described above, for $16 \mathrm{~h}$ at $65^{\circ} \mathrm{C}$. Blots were washed with $2 \times \mathrm{SSC}, 0.1$ per cent SDS $(15 \mathrm{~min})$ followed by $0.1 \times \mathrm{SSC}, 0.1$ per cent $\operatorname{SDS}(2 \times 15 \mathrm{~min})$ and then exposed to Kodak XAR-5 film between intensifying screens at $-70^{\circ} \mathrm{C}$.

\section{Copy number reconstructions}

Copy number reconstructions were carried out by slotblot analysis according to Cullis et al. (1984). Copy number sizes used for the reconstructions were: 5000 $10,000,25,000,50,000,100,000$ and 250,000 . Five micrograms of total genomic DNA (equivalent to $3.0 \times 10^{6}$ genomes) was used to compare with these standards. The genome size was taken as $1.7 \mathrm{pg}$ per haploid genome (Bennett \& Smith, 1991). Densitometry measurements were taken from the exposed autoradiographs and analysed using the UVP gel documentation system SW2000 (UVP Ltd) to estimate the copy numbers.

\section{RNA isolation}

Leaves were frozen in liquid nitrogen, ground into a fine powder and added to three volumes (w:v) of extraction buffer containing $100 \mathrm{mM}$ Tris $\mathrm{pH} 9.0 / 200$ $\mathrm{mM} \mathrm{NaCl} / 5 \mathrm{mM}$ DTT/1 per cent SDS/20 mM EDTA. The tissue was thawed and dispersed with a Polytron homogenizer for $1 \mathrm{~min}$ and the solution phenol-chloroform extracted. The final aqueous phase was removed and adjusted to $2 \mathrm{M} \mathrm{LiCl}$ using an $8 \mathrm{M} \mathrm{LiCl}$ stock solution. The solution was left to stand at $4^{\circ} \mathrm{C}$ over-night and centrifuged at $10,000 \mathrm{~g}$ at $4^{\circ} \mathrm{C}$ for $10 \mathrm{~min}$. The supernatant was discarded and the pellet washed in 3 $\mathrm{ml} 2 \mathrm{M} \mathrm{LiCl}$ and re-pelleted by centrifugation at 10,000 $g$ at $4^{\circ} \mathrm{C}$ for $10 \mathrm{~min}$. The supernatant was discarded and the pellet redissolved in $3 \mathrm{ml} 2 \mathrm{M} \mathrm{LiCl}$. The washing and centrifugation steps were repeated and the pellet dissolved in $1.5 \mathrm{ml} 10 \mathrm{mM}$ Tris $\mathrm{pH} 7.0 / 1 \mathrm{mM}$ EDTA. After centrifugation at $10,000 \mathrm{~g}$ at $4^{\circ} \mathrm{C}$ for 20 min to remove insoluble debris, the supernatant was transferred to a clean tube and ethanol precipitated. The RNA was dissolved in $10 \mathrm{mM}$ Tris $\mathrm{pH} 7.5 / 1 \mathrm{mM}$ EDTA.

\section{Slot blots}

Five $\mu \mathrm{g}$ and $10 \mu \mathrm{g}$ samples of total RNA and $5 \mathrm{ng}$ of plasmid DNA were slot-blotted onto Hybond-N nylon membranes (Amersham). Blots were pre-hybridized in the buffer described above for $1 \mathrm{~h}$ at $65^{\circ} \mathrm{C}$. The plasmid inserts were released by digestion with EcoRI, purified by electrophoresis and Qiaex gel extraction (Hybaid Ltd) and labelled by primer extension (Feinberg \& Vogelstein, 1984). Pre-hybridized blots were hybridized with $50 \mathrm{ng}$ of labelled probe in the buffer described above for $16 \mathrm{~h}$ at $65^{\circ} \mathrm{C}$. Blots were washed with $2 \times \mathrm{SSC}, 0.1$ per cent SDS $(2 \times 15 \mathrm{~min})$ followed by $0.1 \times$ SSC, 0.1 per cent SDS $(2 \times 15 \mathrm{~min})$ and then exposed to Kodak XAR-5 film between intensifying screens at $-70^{\circ} \mathrm{C}$.

\section{Northern blots}

Northern blots were prepared as described in Sambrook et al. (1989). The blots were pre-hybridized at $68^{\circ} \mathrm{C}$ in $6 \times \mathrm{SSC}, 2 \times$ Denhardt's reagent, 0.1 per cent SDS containing $500 \mu \mathrm{g} \mathrm{ml}^{-1}$ denatured salmon sperm DNA for $1 \mathrm{~h}$ and were hybridized for $16 \mathrm{~h}$ with $50 \mathrm{ng}$ of labelled probe in the same buffer at $68^{\circ} \mathrm{C}$. Four washes were performed: $1 \times \mathrm{SSC}, 0.1$ per cent SDS at room temperature for $20 \mathrm{~min}$ and then three washes of $0.2 \times \mathrm{SSC}, 0.1$ per cent SDS at $68^{\circ} \mathrm{C}$ for 20 min each. Following the washes, blots were exposed to Kodak XAR-5 film between intensifying screens at $-70^{\circ} \mathrm{C}$. 


\section{Southern blots}

Digested $R$. acetosa DNA ( $7 \mu \mathrm{g}$ ) was fractionated on 0.7 per cent TBE agarose gels and transferred to nylon membranes (Hybond N, Amersham) as described by Sambrook et al. (1989). Blots were pre-hybridized, hybridized, washed and autoradiographed as detailed for colony blots above.

\section{Chromosome preparations}

Meiotic material. Immature buds from male Rumex acetosa were fixed and stored in Carnoy's solution (6:3:1, absolute, ethanol:chloroform:glacial acetic acid). Anthers were dissected in 70 per cent ethanol. They were then tapped out and squashed in 45 per cent acetic acid. After squashing, the coverslips were removed with liquid nitrogen. The slides were ethanol dehydrated and stored dessicated at $-20^{\circ} \mathrm{C}$.

Mitotic material. Roots were pre-treated with a saturated solution of $\alpha$-bromonapthalene overnight at $4^{\circ} \mathrm{C}$, fixed and stored in 3:1 absolute ethanol: glacial acetic acid. Meristems were dissected in 45 per cent acid, tapped out and squashed. The coverslips were removed in liquid nitrogen. The slides were ethanol dehydrated and stored dessicated at $-20^{\circ} \mathrm{C}$.

Slides used in both procedures were subbed with $3 \times$ SSC $/ 1 \times$ Denhardt's solution as described in Mouras et al. (1987).

\section{In situ hybridization}

The method used for in situ hybridization was as described in Clark et al. (1989) with the exception that the antibody amplification times for the anti-biotin IgG and biotinylated anti-goat $\operatorname{lgG}$ were varied (details are given in the results). The time for the incubation with the biotin complex was $30 \mathrm{~min}$.

\section{C-banding}

C-banding was performed by methods including those of Linde-Laursen (1975), Schwarzacher et al. (1980), Pijnacker \& Ferwerda (1984) and Hutchinson, J. (personal communication).

\section{Fluorochrome banding}

DAPI/CMA 3 /DA (4',6-diamino-2-phenylindole/chromomycin A3/distamycin A) banding was carried out according to Schwarzacher \& Schweizer (1982).

\section{DNAase1 sensitivity experiments}

The DNAase1 sensitivity assay was carried out as described in Kerem et al. (1984). Mitotic chromosome spreads were prepared as described above, with the omission of the ethanol dehydration step, and used within one hour of preparation. Th detection system used was biotin-streptavidin-horseradish peroxidase with DAB (diaminobenzidine).

\section{Results}

\section{The isolation of repeated sequence clones}

Genomic DNA was isolated from both male and female plants of $R$. acetosa. No attempt was made to separate the nuclear DNA from the chloroplast and mitochondrial DNAs. Digestion of the DNA samples with restriction enzymes revealed repeated DNA sequences when the digested DNA was separated on agarose gels and stained with ethidium bromide (Fig. 1).

In order to isolate repeated sequence clones, a small plasmid clone bank (approximately 1200 clones) was generated by cloning EcoRI-digested total $R$. acetosa DNA into the EcoRI site of pUC18 and transforming the ligation mixture into $E$. coli JM109. To identify rDNA clones, colony lifts of the clone bank were first hybridized with the insert (obtained by digestion with EcoRI) from the plasmid pTA71 which contains a DNA copy of the $18 \mathrm{~S}$ and $26 \mathrm{~S}$ ribosomal RNAs from wheat (Gerlach \& Bedbrook, 1979). No rDNA clones were detected. The colony lifts were then hybridized to nick-translated total DNA from a $R$. acetosa male. Colonies giving a strong hybridization signal were identified as putative repeated sequence containing clones. Ninety-three such clones were isolated.

The selected clones were further analysed by crosshybridization experiments which separated the clones into seven major classes (Table 1). In order to assess whether the clones contained repeated sequence DNA and their copy number in the Rumex genome, the clones were further characterized by hybridization to Southern blots of EcoRI digested $R$. acetosa DNA and slot blot copy number reconstructions. In these and subsequent experiments, one member of each of the seven classes was examined.

The clones were also tested as to whether they represented transcribed sequences by hybridization against RNA dot blots and Northern blots. Only one of the seven clones, pRa141, showed transcriptional activity. Details of the different classes of clone are given below in Table 1 . 


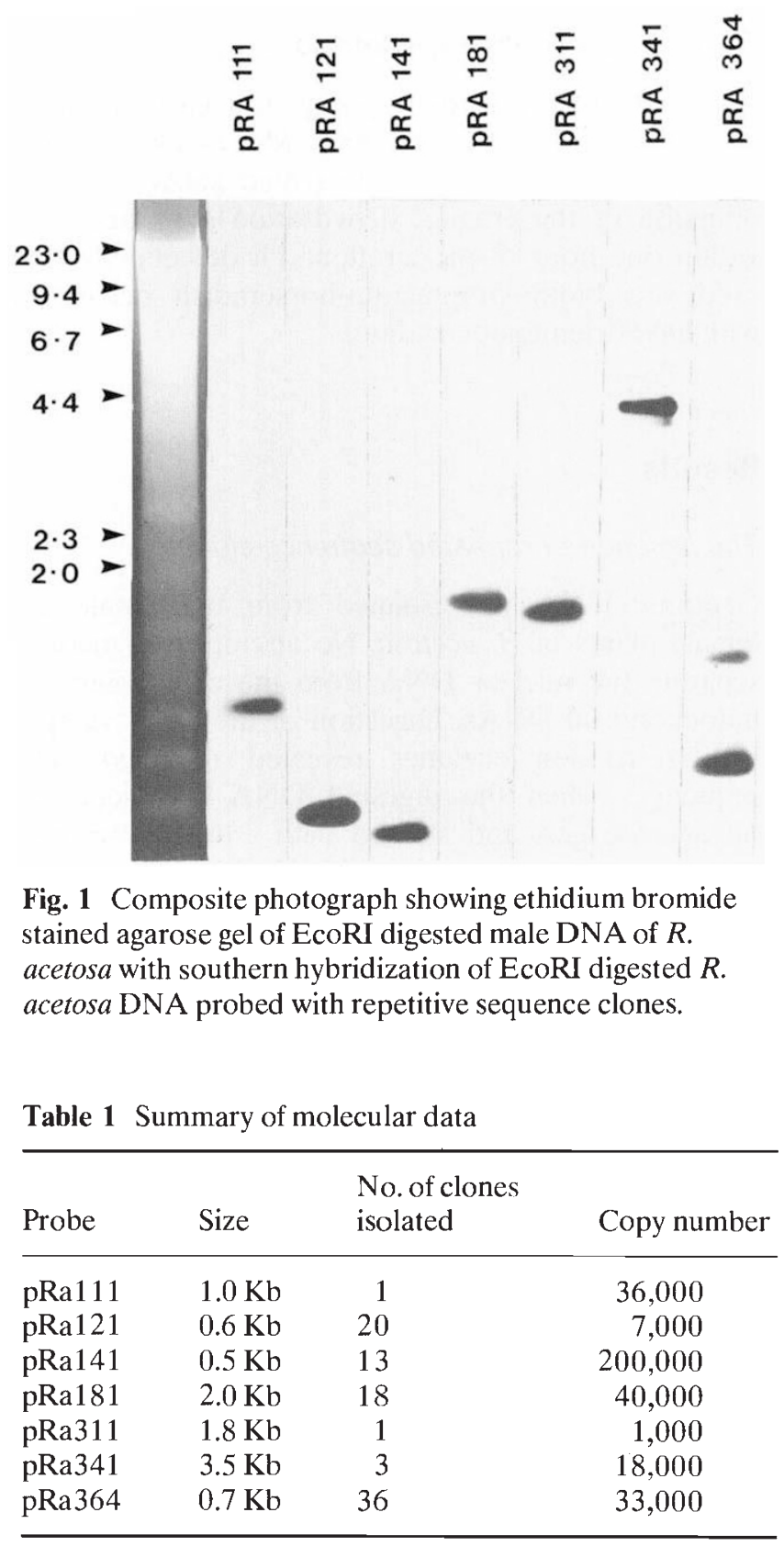

pRa111

This sequence was present in the clone bank as a single clone. The size of the insert was $1 \mathrm{~kb}$ and hybridized to a band of similar size on a Southern blot of EcoRI digested $R$. acetosa DNA (Fig. 1). The copy number was determined as 36,000 which represents 2.1 per cent of the Rumex genome.

\section{pRa121}

This was one of the most highly represented repeated sequence clones, with 20 individual clones in the cross-

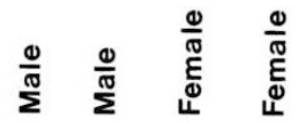

$$
\begin{aligned}
& \text { ำ }
\end{aligned}
$$
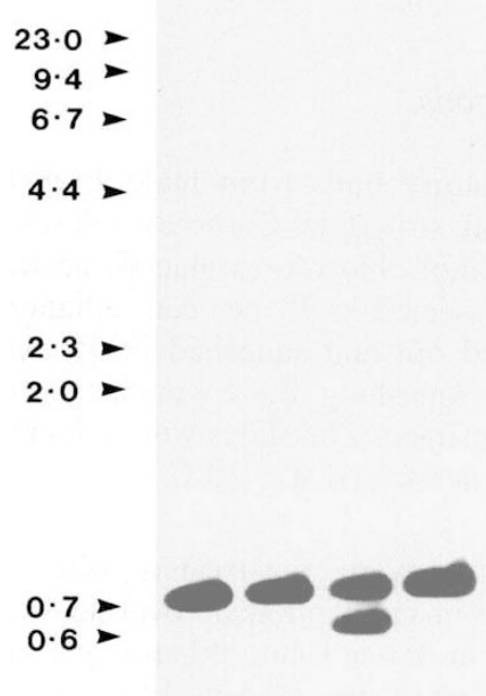

Fig. 2 Southern hybridization of EcoRI digests of male and female DNA (plant codes included) probed with pRa121. Note extra band on FB3 track.

hybridizing class out of the total of 93 . The size of the insert size was $0.6 \mathrm{~kb}$. Hybridization to a Southern blot of EcoRI digested $R$. acetosa DNA revealed a single band of similar size (Fig. 1). However, in one plant (FB3), containing supernumerary segments, two bands were produced of approximately $0.6 \mathrm{~kb}$ and $0.5 \mathrm{~kb}$, respectively (Fig. 2). The copy number was estimated at 7000 , which represents 0.3 per cent of the genome of $R$. acetosa.

\section{pRa141}

This clone was characteristic of the class which represented 12 per cent (13) of the isolated clones. Both the insert size and the hybridizing fragment on the Southern blot of EcoRI digested $R$. acetosa DNA were 0.5 $\mathrm{kb}$ (Fig. 1). This was the most highly repeated sequence in terms of copy number which was estimated at 200,000 , or 5.8 per cent of the genome. When the insert from pRa141 was hybridized to slot blots of total leaf RNA from $R$. acetosa, there was evidence of transcriptional activity. Further testing on Northern blots revealed a single transcript of $1 \mathrm{~kb}$ (Fig. 3). 


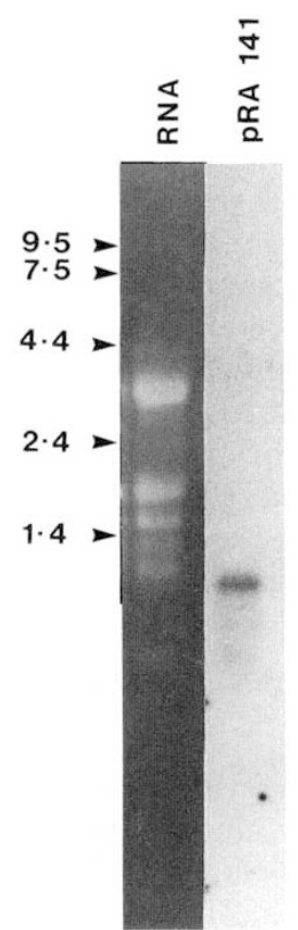

Fig. 3 Composite photograph showing ethidium bromide stained agarose gel of $R$. acetosa total leaf RNA and Northern blot probed with pRa141.

\section{pRa181}

pRa181 represents a class of clone containing 18 members which represents 19 per cent of the isolated clones. The insert size of this clone was $2 \mathrm{~kb}$. Hybridization to Southern blots of EcoRI digested $R$. acetosa DNA produced a single hybridizing fragment of approximately $2.0 \mathrm{~kb}$ (Fig. 1). The copy number was determined as 40,000, 4.7 per cent of the genome.

\section{pRa311}

This clone contained an insert of $1.8 \mathrm{~kb}$ which hybridized to a single fragment of approximately $1.5 \mathrm{~kb}$ on Southern blots of EcoRI digested $R$. acetosa DNA (Fig. 1). This sequence has the lowest copy number with approximately 1000 copies and therefore comprised 0.06 per cent of the $R$. acetosa genome. The sequence contained in pRa311 was present in the clone bank as a single clone.

\section{pRa341}

pRa341 is characteristic of a class of clones containing three members. This class had the largest insert size of the seven clones isolated $(3.5 \mathrm{~kb})$. Hybridization of the insert from pRa341 to Southern blots of EcoRI
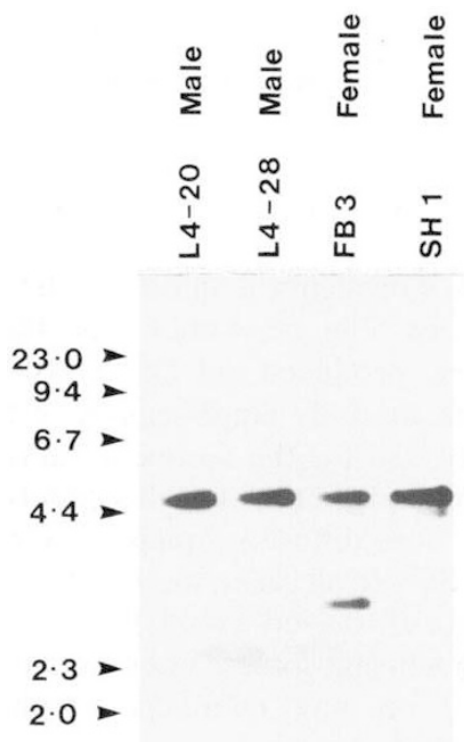

Fig. 4 Southern hybridization of EcoRI digests of male and female DNA (plant codes included) probed with pRa341. Note extra band on FB3 track.

digested $R$. acetosa DNA usually identified a single hybridising fragment of $4.2 \mathrm{~kb}$ (Fig. 1). However a second fragment of $2.6 \mathrm{~kb}$ was identified in Southern blots of DNA extracted from plants with supernumerary segments (Fig. 4). Copy number reconstructions gave a value of 18,000 . This represents 3.7 per cent of the genome.

\section{pRa364}

pRa364 is characteristic of a large class of clones containing 36 members. These clones contained one of the smallest inserts $(0.7 \mathrm{~kb})$ of the seven classes. Hybridization of the insert from pRa364 to Southern blots of $E c o$ RI digested $R$. acetosa DNA identified two hybridizing fragments of $1.2 \mathrm{~kb}$ and $0.6 \mathrm{~kb}$ (Fig. 1). The copy number was determined at 33,000 which represents 1.35 per cent of the genome.

\section{Physical localization of repeated sequences}

Physical localization of the seven sequences was achieved using in situ hybridization. The seven clones were individually hybridized to $R$. acetosa mitotic chromosomes. Hybridization to mitotic chromosomes (using $45 \mathrm{~min}$ for the primary antibody and $25 \mathrm{~min}$ for the second antibody) gave complete coverage of the chromosomes, indicating the dispersed nature of the probes throughout the genome. $R$. acetosa root tips, from which the cytological preparations were made, have a low mitotic index, even in specially induced 
conditions. Therefore, the majority of the cytological work was carried out on meiotic preparations $\langle 1.5 \mathrm{~h}$ for the primary antibody and $0.75 \mathrm{~h}$ for the secondary antibody).

When the seven probes were hybridized to meiotic chromosomes, both metaphase-I bivalents and the more elongated prophase-I bivalents, a random "polkadot' pattern was produced (Fig. 5), rather than the overall blanket coverage produced on the mitotic chromosomes. Increased antibody amplification $(2 \mathrm{~h}$ for the primary antibody, $1 \mathrm{~h}$ for the secondary antibody and $1 \mathrm{~h}$ for the complex) did not alter this pattern of staining, even on the more diffuse prophase-I bivalents (Clark \& Parker, 1992). In all cases, the R. acetosa repeated sequences were dispersed along the autosomes, the $\mathrm{X}$ and both $\mathrm{Y}$ chromosomes. There was no concentration of signal on any members of the chromosome complement.

In order to test whether homologous sequences were present in related Rumex species, the seven probes isolated were then applied to three other species of the Rumex acetosa complex, all of which carry the XX/ $\mathrm{XY}_{1} \mathrm{Y}_{2}$ sex determining system (Wilby \& Parker, 1988). All seven classes cloned sequences hybridized to meiotic chromosomes of the perennial species $R$. thyrsiflorus and $R$. thyrsoides and identical patterns of 'polka-dot' distributions were obtained to that in $R$.

(a)

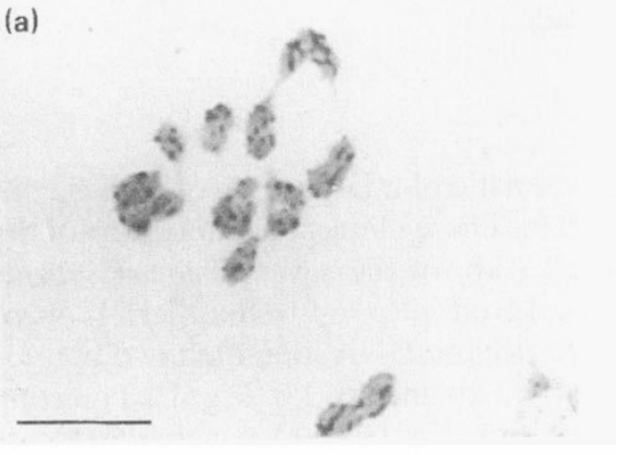

(b)

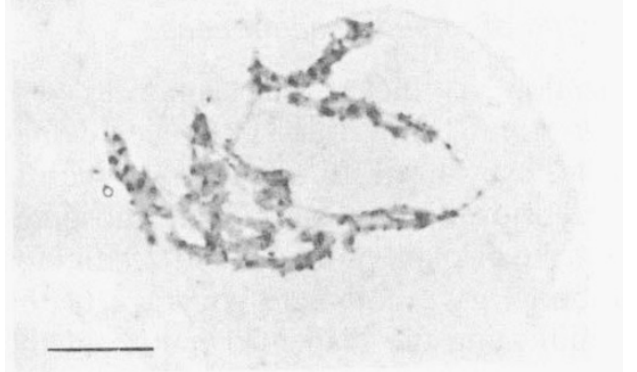

Fig. 5 In situ hybridization of pRa121 to: (a) Meiotic Metaphase I chromosomes of R. acetosa; (b) Late Prophase I chromosomes. Scale bar $=10 \mu \mathrm{m}$. acetosa. The hybridization was, however, less intense than with $R$. acetosa. Hybridization to the more distantly related desert annual $R$. rothschildianus was less intense than with $R$. thyrsiflorus and $R$. thyrsoides. The experimental conditions had to be changed for this species in order to achieve the in situ hybridization with a reduction in the denaturation step from $50 \mathrm{~s}$ to $30 \mathrm{~s}$. This change in conditions may be attributed to a difference in meiotic chromosome structure between $R$. acetosa and $R$. rothschildianus. The reduction in the intensity of hybridization signals in the perennial species $R$. thyrsiflorus and $R$. thyrsoides may be due to evolutionary divergence of the $R$. acetosa-derived sequences in these related species (Fig. 6).

\section{Analysis of the structure of the chromosomes of $\mathrm{R}$. acetosa}

A number of different techniques were tried in order to assess the chromatin structure of the chromosomes in the genome of $R$. acetosa. These included DNAse-I sensitivity experiments, C-banding and fluorochrome banding with several different fluorochromes.

In animal chromosomes, regions containing actively transcribing genes are sensitive to digestion by DNAase-I (Kerem et al., 1984). Therefore, the degree of sensitivity is a measure of the relative transcriptional activity of a chromosome and can be monitored by in situ nick translation following digestion using the nonradioactive detection system biotin-streptavidinhorseradish peroxidase with DAB. This system was adapted for use with mitotic plant chromosomes. $R$. acetosa mitotic chromosomes were subjected to DNAse-I treatment to this end. DAB coverage of chromosomes in individual cells was patchy probably as a result of interference from cell wall components, a situation analogous to the problems encountered with in situ hybridization of low copy number sequences (Clark et al., 1989). Analysis of several slides however showed that all chromosomes, both autosomes and sex chromosomes were transcriptionally active over their

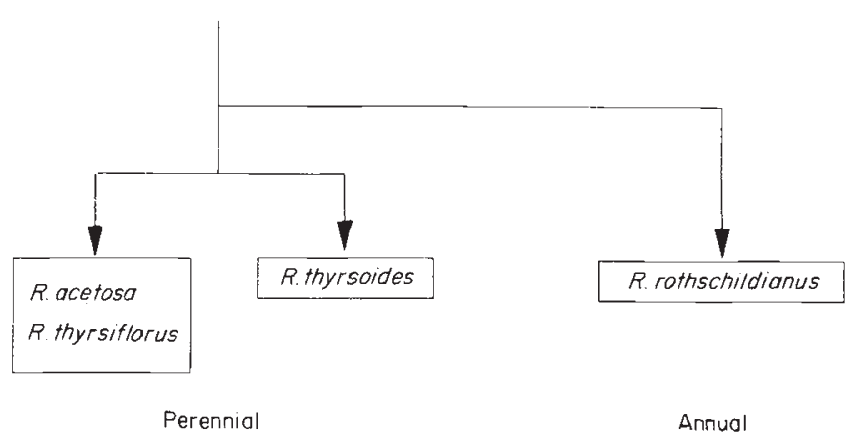

Fig. 6 Karyotypic relationships between Rumex species. 
Fig. 7 DNAse I sensitivity test on: (a) Prophase chromosomes, (b) Metaphase chromosomes. Whole cell $2 \mathrm{n}=2 \mathrm{x}=15$, $\mathrm{XY}_{1} \mathrm{Y}_{2},(\mathrm{c})$ Metaphase chromosomes. Broken cell, $2 \mathrm{n}=13$. Scale bar $=10 \mu \mathrm{m}$.

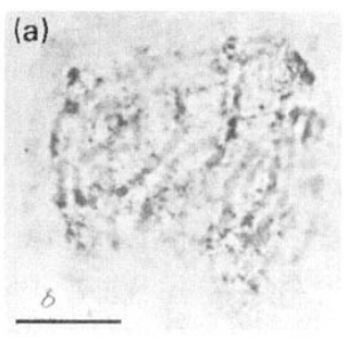

entire length. There was no discrete pattern of signal and the labelling was of a random nature (Fig. 7).

Constitutive heterochromatin is usually demonstrable cytologically by C-banding techniques. Many methods were attempted to C-band the chromosomes of $R$. acetosa. The protocols for $\mathrm{C}$-banding produced no bands and no morphological deterioration of the chromosomes. Drastic increases in the times of treatments resulted in the chromosomes being washed from the slide. No intermediate stages were observed with labelled chromosomes. Harsh treatments such as $\mathrm{N}$-banding were also tried, but no banding pattern was produced. Failure to detect C-bands using any technique suggests that there is, in fact, no constitutive heterochromatin in the genome of $R$. acetosa. C. Ruiz Rejon (personal communication) has reached the same conclusion using Spanish material.

Fluorochrome banding has been successfully used to define chromosomal regions with specific nucleotide compositions. The fluorochrome DAPI/AMD/CMA3 specifically binds to $\mathrm{G}-\mathrm{C}$ rich regions of the chromosomes (Schweizer, 1981). When applied to mitotic chromosomes spreads of $R$. acetosa, fluorescence was limited to the nucleolar organizer region of chromosome 3 which gave a strongly fluorescing signal and a small terminal portion of each $\mathrm{Y}$ which showed fluorescence (Fig. 8). It seems likely that the faint $Y$ fluorescence was emitted by the euchromatic pairing regions of the $\mathrm{Y}$ chromosomes, but studies of highly acrocentric $Y s$ are needed to establish this. The $Y$ fluorescence was so faint it proved impossible to photograph. Meiotic studies did not yield satisfactory results concerning the locations of these faintly staining Y-bands. In addition, bright florescence was observed around the centromeres of $\mathrm{B}$ chromosomes which are commonly found in $R$. acetosa.

\section{Discussion}

Our understanding of the DNA sequence organization of the plant genome is mainly limited to a few crop species, such as wheat and tomato, and to Arabidopsis. Rumex acetosa is unusual in that it is a dioecious species with highly differentiated sex chromosomes.

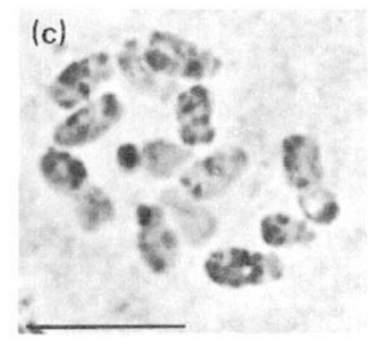

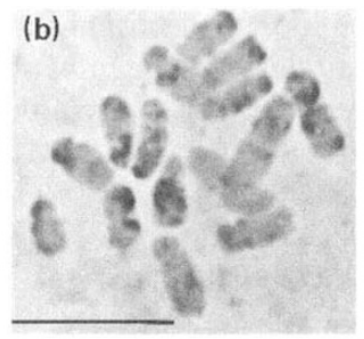

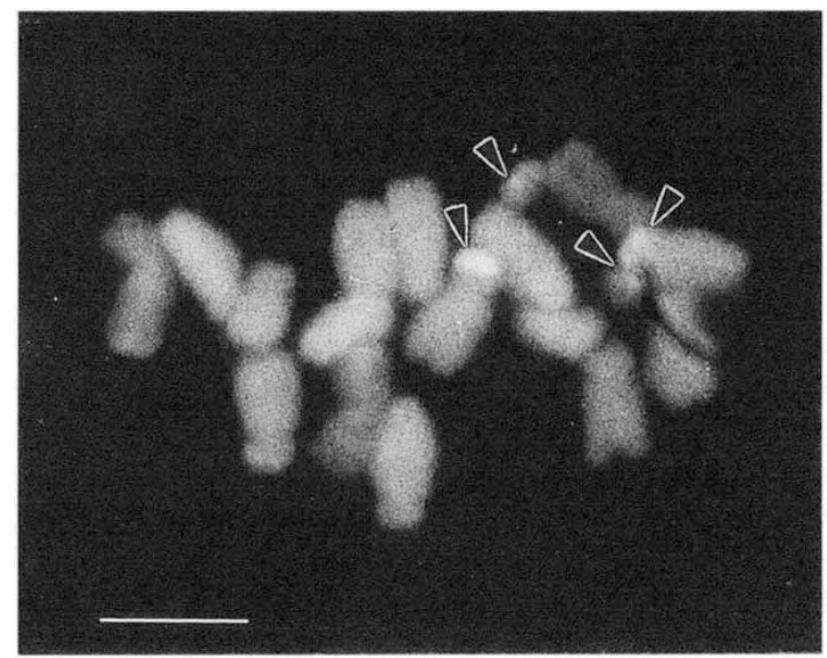

Fig. 8. DAPI/AMD/CMA 3 fluorochrome stained $R$. acetosa chromosomes. Bright fluorescence present on the two nucleolar organiser regions and centromeres of the two $\mathrm{B}$ chromosomes (arrowed). $2 \mathrm{n}=2 \mathrm{x}=17, \mathrm{XYY}+2 \mathrm{Bs}$. Scale $\mathrm{bar}=10 \mu \mathrm{m}$.

This study presents an integrated molecular and cytogenetic analysis of some repeated sequences present in the genome of Rumex acetosa. Few plant species have been extensively investigated with regard to their repeated sequences and even fewer with this integrated approach (Jones \& Flavell, 1982a; Kato et al., 1985; Ganal et al., 1988). It is perhaps surprising that there has not been more research on such sequences, given the fact that they account for such a large proportion of the genome in many plant species.

Clones for seven non-homologous repeated sequences have been isolated from Rumex acetosa, a higher number than has been reported in most previous studies on plants. However, there is no doubt that there are many other repeated sequences in the genome as is indicated by ethidium bromide stained gels of genomic DNA digested with other restriction enzymes (Ainsworth, unpublished). The work of Bedbrook et al. (1980) isolated four non-homologous families from rye (480 bp, $610 \mathrm{bp}, 630 \mathrm{bp}, 120 \mathrm{bp}$ ). There were found to map to the heterochromatic 
blocks on the terminal regions of each chromosome. Many further molecular studies have been carried out on rye and other repeated sequences are frequently reported (Appels et al., 1981; Appels \& McIntyre, 1985; McIntyre et al., 1990; Guidet et al., 1991). Such tandemly repeated sequences appear to be widespread in plants and are often located in blocks of heterochromatic DNA, such as centromeric regions, telomeres and knob heterochromatin. In addition to rye, these satellite-type sequences have been described in maize (Dennis \& Peacock, 1980) and rice (De Kocho et al., 1991) and have copy numbers in the hundreds to high thousands.

The isolation of repeated sequences is generally carried out by total digestion of genomic DNA followed by cloning into a plasmid vector with or without prior size selection (most repetitive sequences being in the size range $500 \mathrm{bp}$ to $2 \mathrm{~Kb}$ ). In this study, the $R$. acetosa DNA was digested with EcoRI and the largest repetitious plant DNA insert cloned into pUC18 was $3.5 \mathrm{~Kb}$. No ribosomal sequences were cloned, despite their repeated nature, presumably due to the expected large size of the fragments produced by EcoRI digestion. In wheat, the EcoRI fragment from pTA71, containing the $26 \mathrm{~S}$ and $18 \mathrm{~S}$ rRNAs, is approximately $9 \mathrm{~kb}$ (Gerlach \& Bedbrook, 1979). This isolation procedure is also constrained by the restriction enzyme used in the cloning procedure and there are likely to be other repeated sequence families which would be identified using other restriction enzymes. This problem was identified by Zamir \& Tanksley (1988) who recommended shearing the DNA to overcome restriction enzyme bias. The seven repeated sequences identified here alone account for 18 per cent of the genome of $R$. acetosa. However, due to the reasons mentioned above, these sequences are obviously not representative of all of the repeated sequences present in the Rumex acetosa genome.

A difference between these $R$. acetosa sequences and those isolated in other studies is their dispersed nature. Comprehensive studies on other species such as Vicia, Secale cereale and Lycopersicon esculentum (Jones \& Flavell, 1982b; Kato et al., 1985; Ganal et al., 1988) have reported a comparable number of sequences, but on mapping by in situ hybridization the sequences were found at several sites but tandem in organization within each site. The reason for this anomaly may be the restriction enzyme bias described earlier. A theory of the evolution of repeated sequences is that the more ancient the genome the more dispersed the sequences (Dover \& Flavell, 1982). Breeding may select for particular arrangements of repeated sequences (Flavell, 1986), particularly if they are in heterochromatin which may exert a position effect on genes in the vicinity (Bostock, 1980). It is, perhaps, surprising that the tandem repeats observed on agarose gels of EcoRI digested $R$. acetosa DNA were not cloned. A short repeat defined by EcoRI has however been isolated from $R$. acetosa which appears to be limited to the $\mathrm{X}$ and $\mathrm{Y}$ chromosomes (C. Ruiz Rejon, personal communication).

Recent studies show that some dispersed sequences are retroviral in origin (Johns et al., 1985; Voytas et al., 1988; Sentry \& Smyth, 1989) or are disabled transposable elements (Shepherd et al., 1982; Harberd et al., 1987; Schwarz-Sommer et al., 1987). Sequence analysis has also shown that there are footprints in the genome from transposable elements which leave behind short sequence motifs when they excise (Schwarz-Sommer et al., 1985). Preliminary sequence analysis has shown that the sequence in pRA121 is related to a Cauliflower Mosaic Virus-like sequence. This type of dispersed repeated sequence would be consistent with it being a retrotransposon-type sequence. Most of the retroviral sequences identified in plants so far have been low copy number, for example, Ta1 is present in 1 to 3 copies in Arabidopsis (Voytas et al., 1988), Bs1 in 1-5 copies in wheat plant (Johns et al., 1985) and Tos 1 and Tos 2 in the rice genome (Hirohika et al., 1992). By contrast, the retrotransposon del has been shown to be present in 13,000 copies per haploid genome in Lilium henryi (Sentry \& Smyth, 1989). Studies in wheat suggest that up to 10 per cent of the genome consists of fixed retrotransposon-like sequences (Flavell, 1986). pRA121 has been estimated to be present at 7000 copies, i.e. 0.3 per cent of the genome.

Only one of the seven sequences, pRA141, was shown to be transcriptionally active. It is, however, possible that the transcription detected on Northern blots comes from read through from a neighbouring promoter. This could be tested by analysis of the mRNA structure or IPCR (Inverse Polymerase Chain Reaction) of the flanking sequence DNA. Data on the transcription of other repeated sequences are scarce and few transcribing repeats have been identified (Leclerc \& Siegel, 1987). General statements to the effect that repeated sequences are not transcribed are misleading in that no comprehensive studies have been carried out and there is an associated lack of knowledge surrounding function. Studies on retrotransposons have so far identified only one which is actively transcribed in cell culture (Tnt1; Grandbastien et al., 1989).

The cytological characterization of the sex chromosome of $R$. acetosa contradicts previous findings that the Y chromosomes are inert heterochromatic structures. Localisation of the seven repeated sequences 
reveals no major differences in distribution between the autosomes, the $\mathrm{X}$ and the $\mathrm{Y}$ chromosomes. There is no evidence, therefore, of a unique set of sequences characterizing the $Y$ chromosomes. Specific sequences may exist, but alternative cloning strategies would be required to isolate them. This overall similarity in chromosome structure between sex chromosomes and autosomes is confirmed by the fluorochrome and DNase-I banding studies. The $\mathrm{Y}$ chromosomes are transcriptionally active and part of this may be due to the repeated sequence pRa141. Other Y-borne sequences however, may also be active in transcription. It is concluded, therefore that the heterochromatization of the $\mathrm{Y}$ chromosomes is not constitutive, but rather facultative. This is the first demonstrations of facultative heterochromatin in a plant system. These observations bear out inferences made by Parker \& Clark (1991) about Y activity during sporophytic development from studies of $\mathrm{Y}$ deletions and interchanges.

Repeated sequences are ubiquitous. In plants their importance is heightened as they are held to be mainly responsible for the large differences in genome size between species (Flavell et al., 1974). Extensive studies have been carried out in relatively few species but some patterns are emerging, such as the increasing identification of extinct retroviral sequences and transposable elements. In investigations of genome organization, sequencing data are likely to be most useful when combined with cytogenetic localization by in situ hybridization. This combined approach in other systems such as wheat and Lilium should give a clearer picture of the organization of the large genomes of flowering plants.

\section{Acknowledgements}

This work was supported by a research grant from the Science and Engineering Research Council.

\section{References}

APPELS, R., DENNIS, E. S., SMYTH, D. R. AND PEACOCK, W. J. 1981. Two repeated DNA sequences from the heterochromatic regions of rye (Secale cereale) chromosomes. Chromosoma, 84, 265-277.

APPELS, R. AND MCINTYRE, C. L. 1985. Cereal genome organization as revealed by molecular probes. Oxford Surveys of Plant Mol. Cell. Biol., 2, 235-252.

BEDBROOK, I. R., JONES, I., O'DELL, M., THOMPSON, R. D. AND FLAVELL, R. B. 1980. A molecular description of telomeric heterochromatin in Secale species. Cell, 19, 545-560.

BENNETT, M. D., SMITH, J. B. AND HESLOP-HARRISON, J. S. 1982. Nuclear DNA amounts in angiosperms Proc. Soc. Lond. B., 216, 179-201.
BENNETT, M. D. AND SMITH, J. B. 1991. Nuclear DNA amounts in angiosperms. Phil. Trans. R. Soc. Lond. B., 334, 309-345.

BosTock, C. 1980. A function for satellite DNA? T. I. B. S., 5 , 117-119.

ClARK, M. S., KARP, A. AND ARCHER, s. 1989. Physical mapping of the B hordein loci on barley chromosome 5 by in situ hybridization. Genome, 32, 925-929.

CLARK, M. S. AND PARKER, J. S. 1992. In situ hybridization of plant meiotic and mitotic chromosomes: differences in signal detection. Biotechnic and Histochemistry, 67, 265-267.

CULLIS, C. A., RIVIN, C. J. AND WALBOT, V. 1984. A rapid procedure for the determination of the copy number of repetitious sequences in eukaryotic genomes. Plant Mol. Biol. Rep., 2, 24-31.

DE KOCHO, A., KIEFER, M. C., CORDESSE, F., REDDY, A. S. AND DELSENY, M. 1991. Distribution and organization of a tandemly repeated 352-bp sequence in the oryzae family. Theor. Appl. Genet., 82, 57-64.

DENNIS, E. S., GERLACH, W. L. AND PEACOCK, W. J. 1980. Identification of polypyrimidine-polypurine satellite DNAs in wheat and barley. Heredity, 44, 349-366.

DENNIS, E. S. AND PEACOCK, w. J. 1980. Knob heterochromatin homology in maize and its relatives. J. Mol. Evol., 20, $341-350$.

Dover, G. A. AND flaVell, R. B. 1982. Genome Evolution. Pub. Academic Press, London.

FEINBERG, A. P., VOGELSTEIN, B. 1984. A technique for radiolabelling DNA restriction endonuclease fragments to high specific activity. Anal. Biochem., 137, 266-267.

FLAVELL, R. B. 1986. Repetitive DNA and chromosome evolution in plants. Phil. Trans. R. Soc. Lond. B., 312, 227-242.

FLAVELL, R. B., BENNETT, M. D., SMITH, J. B. AND SMITH, D. B. 1974. Genome size and the proportion of repeated nucleotide sequence DNA in plants. Biochem. Genet., 12, 257-271.

GANAL, M. W., LAPITAN, N. V. L. AND TANKSLEY, S. D. 1988. A molecular and cytogenetic survey of major repeated DNA sequences in tomato (Lycopersicon esculentum). Mol. Gen. Genet., 213, 262-268.

GERLACH, W. L. AND BEDBROOK, J. R. 1979. Cloning and characterisation of ribosomal RNA genes from wheat and barley. Nucl. Acids. Res., 7, 1869-1885.

GRANDBASTEIN, M.-A., SPIELMANN, A. AND COBOCHE, M. 1989. Tnt1, a mobile retroviral-like transposable element of tabacco isolated by plant cell genetics. Nature, 337, 376-380.

GRELlET, F., DELCASSO, D., PANABIERES, F. AND DELSENY, M. 1986. Organization and evolution of a higher plant Alphoid-like satellite DNA sequence. J. Mol. Biol., 187, 495-507.

GUIDET, F., RAGOWSKY, P., TAYLOR, C., SONG. W. AND LANGRIDGE, P. 1991. Cloning and characterization of a new rye specific repeated sequence. Genome, 34, 81-87.

HARBERD, N. P., FLAVELL, R. B. AND THOMPSON, R. D. 1987. Identification of a transposon-like insertion in a $G l u-1$ allele of wheat. Mol. Gen. Genet., 209, 326-332.

HIROHIKA, H., FUKUCHI, A. AND KIKUCHI, F. 1992. Retrotransposon families in rice. Mol. Gen. Genet., 233, 209-216.

HUTCHINSON, J. AND LONSDALE, D. M. 1982. The chromosomal 
distribution of cloned highly repetitious sequences from hexaploid wheat. Heredity, 48, 371-376.

JOHNS, M. A., MotTinger, J. AND FREELING, M. 1985. A low copy, copia-like transposon in maize. EMBO J., 4, 1093-1102.

JONES, J. D. G. AND FLAVELL, R. B. 1982a. The mapping of highly repeated DNA families and their relationship to C-bands in chromosomes of Secale cereale. Chromosoma, 86, 595-612.

JONES, J. D. G. AND FLAVELL, R. B. 1982b. The structure, amount and chromosomal localization of defined repeated DNA sequence in species of the genus Secale. Chromosoma, 86, 613-642.

KATO, A., YOICHI, I., YAKURA, K. AND TANIFUJI, s. 1985. Sequence analysis of Vicia faba highly repeated DNA: the BamHI repeated sequence families. Plant Mol. Biol., 5, 41-53.

KEREM, B.-S., GOITEIN, R., DIAMOND, G., CEDAR, H. AND MARCUS, M. 1984. Mapping of DNAseI sensitive regions on mitotic chromosomes. Cell, 38, 493-499.

LECLERC, R. F. AND SIEGEL, A. 1987. Characterization of repetitive elements in several Curcurbita species. Plant. Mol. Biol., 8, 497-507.

LEUTWILER, L. S., HOUGH-EVANS, B. A. AND MEYERWITZ, E. M. 1984. The DNA of Arabidopsis thaliana. Mol. Gen. Genet., 194, 15-23.

Linde-LAuRSEN, I. 1975. Geimsa C-banding of the chromosome of 'Emir' barley. Hereditas, 81, 285-289.

MCINTYRE, C. L., PEREIRA, S. MORAN, L. B. AND APPELS, R 1990. New Secale cereale (rye) DNA derivatives for the detection of rye chromosome segments in wheat. Genome, 33 , 635-640.

MOURAS, A. SAUL, M. W., ESSAD, S. AND POTRYKUS, I. 1987. Localisation by in situ hybridization of a low copy number chimeric resistance gene introduced into plants by direct gene transfer. Mol. Gen. Genet., 207, 204-209.

PARKER, J. S. AND CLARK, M. S. 1991. Dosage sex chromosome systems in plants, Plant Sci., 80, 79-92.

PIJNACKER, L. P. AND FERWERDA, M. A. 1984. Geimsa C-banding of potato chromosomes. Can. J. Genet. Cytol., 26, 415-419.

REDDY, A. S., SCRIVASTAVA, v. AND GUPTA-MUKHERJEE, s. 1989. A tandemly repeated DNA sequence from Brassica juncea. Nucl. Acids. Res., 17, 5849.

RIMPAU, J., SMith, D. B. AND Flavell, R. B. 1978. Sequence organization analyses of the wheat and rye genomes by interspecies DNA/DNA hybridization. J. Mol. Biol., 123, 327-359.

SAKOWICZ, T., GALAZKA, G., KONARZEWSKA, A., KWINKOWSKI, M. AND KLYSKIK, J. 1986. An usually high number of direct repeats detected by sequence analysis of the dispersed EcoRI- family fragments in Lupinus luteus L. Planta, 168, 207-213.

SAMBROOK, J., FRITSCH, E. F. AND MANIATIS, T. 1989. Molecular Cloning, A Laboratory Guide. Second edition Pub. C.S.H. Lab. Press, U.S.A.

SENTRY, J. W. AND SMYTH, D. R. 1989. An element with long terminal repeats and its variant arrangements in the genome of Lilium henryi. Mol. Gen. Genet., 215, 349-354.

SCHWARZACHER, T., AMBRos, P., AND SCHWEIZER, D. 1980. Application of geimsa banding to orchid karyotype analysis. Plant Syst. Evol., 134, 293-297.

SCHWARZACHER, T. AND SCHWEIZER, D. 1982. Karyotype analysis and heterochromatin differentiation with geimsa C-banding and fluorescent counterstaining in Cephalanthera (Orchidaceace) Plant Syst. Evol., 141, 91-113.

SCHWARZ-SOMMER, Z., GIERL, A., CUYPERS, H., PETERSON, P. A. AND SAEDLER, H. 1985. Plant transposable elements generate the DNA sequence diversity needed in evolution. EMBO J., 4, 591-597.

SCHWARZ-SOMMER, Z., LECLERCQ, L., GÖBEL, E. AND SAEDLER, H. 1987. Cin4, an insert altering the structure of the A1 gene in Zea mays, exhibit properties of nonviral retrotransposons. EMBO J. 6, 3873-3880.

SCHWEIZER, D. 1981. Counterstain-enhanced chromosome banding. Hum. Genet., 57, 1-14.

SHEPHERD, N. S., SCHWARZ-SOMMER, Z., WIENAND, U., SOMMER, H., DEUMLING, B., PETERSON, P. A. AND SAEDLER, H. 1982. Cloning of a genomic fragment carrying the insertion element Cin 1 of Zea mays. Mol. Gen. Genet., 188, 266-271.

viotTl, A., PRIVITERA, E., SAlA, E. AND POGNA, N. 1985. Distribution and clustering of two highly repeated sequences in the $\mathrm{A}$ and $\mathrm{B}$ chromosome of maize. Theor. Appl. Genet., 70, 234-239.

vOYTAS, D. F. AND AUSABEL, F. M. 1988. A copia-like transposable element family in Arabidopsis thaliana. Nature, 336, 242-244.

WILBY, A. S. AND PARKER, J. S. 1986. Continuous variation in the Y chromosome structure of Rumex acetosa. Heredity, 57, 247-254.

WILBY, A. S. AND PARKER, J. s. 1988. Recurrent patterns of chromosome variation in a species group. Heredity, 61, 55-62.

ZAMIR, D. AND TANKSLEY, S. D. 1988. Tomato genome is comprised largely of fast evolving low copy number sequences. Mol. Gen. Genet., 213, 254-261.

ZUK, J. 1969. Autoradiographic studies in Rumex with special reference to sex chromosomes. Chromosomes Today, 2, 183-187. 